DOI:10.17951/h.2020.54.2.7-19

\begin{tabular}{lcc}
\hline & A N N A L E S \\
UNIVERSITATIS MARIAE CURIE-SKŁODOWSKA \\
LUBLIN - POLONIA \\
SOL. LIV, 2
\end{tabular}

\title{
MIROSŁAW ANTONOWICZ
}

maaw@kozminski.edu.pl

Kozminski University

57 Jagiellońska St., 03-301 Warsaw

ORCID ID: https://orcid.org/0000-0001-7206-0625

\section{ZBIGNIEW TRACICHLEB}

z.tracichleb@pkp-lhs.pl

\section{The Role of the Broad-Gauge Metallurgy Line PKP Linia Hutnicza Szerokotorowa Sp. z o.o. and the Belt and Road Initiative: Transportation in the Development of the Lublin Province}

Keywords: transport corridors; Silk Road; intermodal transport; transport infrastructure

JEL: L92

How to quote this paper: Antonowicz, M., \& Tracichleb, Z. (2020). The Role of the Broad-Gauge Metallurgy Line PKP Linia Hutnicza Szerokotorowa Sp. z o.o. and the Belt and Road Initiative: Transportation in the Development of the Lublin Province. Annales Universitatis Mariae Curie-Skłodowska, sectio H-Oeconomia, Vol. 54, No. 2.

\begin{abstract}
The article presents the railway entity PKP LHS Sp. z o.o. and its role in the development of the New Silk Road. In consequence, the increase in traffic on the Silk Road with the participation of Polish companies translates into the economic development of the Lublin Province and the development of border crossings in that province. The importance of transport corridors and the participation of PKP LHS in the development of those corridors have been highlighted. Investment assumptions have been presented, the effects of which will be visible in a few years, strengthening the potential and economic capabilities of the province.
\end{abstract}




\section{Introduction}

In the literature about the Broad-Gauge Metallurgy Line PKP LHS (hereinafter referred to as PKP LHS), there are only a few studies of the potential of broad-gauge railway line operated by PKP LHS. Meanwhile, railway transportation based on Asian-European lines is developing steadily and its significance is increasing every year (Jakóbowski, Popławski, \& Kaczmarski, 2018). Container imports from Asia to Europe via maritime routes in 2016 reached over 15 million TEU according to the Japan Maritime Center (www 1). As stated in European Commission data (www 2), the total worth of Asia to Europe cargo in 2016 was EUR 773 billion. About 3\% of the goods are imported directly to Poland (www 3). It is a major opportunity for economic development and also a chance to increase budget revenue by customs fees. Is it possible for PKP LHS to become an alternate transport route for Asian cargo transported by sea and air, currently transhipped on EU borders, within ports and standard railway lines? This is the question addressed in this study.

\section{Methodology}

This report uses publicly available data such as GUS reports, regional development strategy and spatial development plans of the Lublin Province, as well as documents and in-house analysis of PKP LHS. By having access to various materials, including unpublished in-house documents, the authors raise the issues of developing a broadgauge metallurgy line and the influence of such a line on the development of the Lublin Province in terms of its economy and markets. This report also refers to investment plans by the sole broad-gauge railway operator in Poland, which actively participates in the Belt and Road Initiative on the national and international levels. Those sources provide reliable regional diagnostics of the Lublin Province and its potential implications for the rest of the country. It has also laid the foundation for further, more advanced research about this region.

\section{Background on the Lublin Province and its railway transport capacity}

From the perspective of rail freight transport, the crucial spot on the map of the Lublin Province is the town of Małaszewicze, located in the second pan-European transport corridor Berlin-Warsaw-Minsk-Moscow-Nizhny Novgorod. Małaszewicze is the EU's largest so-called "dry port" for transhipment between the East and the West. Its daily handling capacity is estimated at 24 thousand tons, and the number of train pairs that can be serviced per day reaches 14. This is also the point where the "European" $1,435 \mathrm{~mm}$ wide and "Eastern European" 1,520 mm wide tracks meet. One of the largest operators in Małaszewicze is PKP Cargo Logistics, which has signed a cooperation agreement 
with Chinese railways. Małaszewicze is a major landmark on the railway transport route from China to the European Union. The ongoing modernisation is intended to improve the capacity of the border crossing significantly. Eventually, 50 pairs of trains per day are to be operated there. The terminals are used not only for transhipment of goods (e.g. train-train, vehicle-train), but also for sorting, packing, and further distribution. Moreover, terminals also provide for customs clearance and other services related to international transport. Customs, phytosanitary, and veterinary services operate there and handle the flow of goods. The Dorohusk-Jagodzin railway crossing also is in the Lublin Province. It is located on the Polish-Ukrainian border and operates both cargo and passenger road and rail traffic. That crossing also includes a section of a broad-gauge track (ca. $31 \mathrm{~km}$ long), and it constitutes the shortest road connecting Gdańsk Pomerania and Mazovia region with Ukraine. With the modernisation of railway line No. 7 and plans to build new intermodal terminals, e.g. in Chelm, the capacity of this border crossing will increase significantly. The Rail Port transhipment terminal in Dorohusk is located nearby. Moreover, the Lublin Container Terminal is located in Drzewce near Nałęczów, next to the Warsaw-Lublin-Dorohusk railway line No. 7. It is the first intermodal terminal in the Province. Containers from trains are transhipped to road transport (1 train per day with up to 60 containers). However, because there is only one side track available, its development capacity is limited. The Lublin region has a number of railway side tracks used for logistic purposes. The biggest potential is in the major transport hubs (Lublin, Dęblin, Łuków, Dorohusk, Hrubieszów, Zamość, and Szczebrzeszyn). Some side tracks are used by forwarding companies. Others are the domain of large enterprises, such as those in Jaszczów which handle trains transporting coal from the "Bogdanka" mine (Program ..., 2017, pp. 49-55). The Lublin Province borders Ukraine $(296.3 \mathrm{~km})$ and Belarus $(171.3 \mathrm{~km})$. This border also constitutes the external border of the European Union. The Province has eight border crossings, three with Belarus and five with Ukraine. The lack of sufficient state investment at the eastern border has limited the potential and capacity of border infrastructure. The Hrubieszów-Izov border crossing, used by the PKP LHS broad-gauge railway line, is of strategic significance for international exchange. Part of railway and road transport is channelled via the Hrebenne-Rawa Ruska border crossing. The newest and most modern Polish-Ukrainian border crossing is Dołhobyczów-Uhrynów. In terms of geographical location, both Poland and the Lublin region constitute an important transit link for European road and rail traffic. However, the potential of Lublin Province has not been fully leveraged, and railway transport and logistics infrastructure call for significant support.

\section{The Belt and Road Initiative}

The Belt and Road Initiative (B\&R) is a geopolitical vision presented by China (Hubner, Rybicka, \& Wieszczycka, 2016, pp. 23-80). The idea behind it is to establish a network of land, sea, and air transport corridors linking China with Europe. 
In this context, the B\&R does not include one corridor, i.e. the railway route from China via Russia (Trans-Siberian Railway) to the Belarusian-Polish Brest-Terespol border crossing and then to Western Europe. One of the variants of the B\&R is the so-called TMTM or TITR (Trans-Caspian International Transport Route) corridor, also known as the "middle corridor". The Belt and Road Initiative is designed to strengthen cooperation between the countries on its entire length. As of this writing, about 70 countries and regions (which together account for $1 / 3$ of the world's GDP and $60 \%$ of the world's population) have confirmed their participation in the project. This is a long-term project aimed at strengthening trade relations between China and Europe. China is the largest exporter worldwide, and it accounts for more than $1 / 4$ of world production. This concept is related to China's efforts to establish international relations with countries involved in the development of these land routes. Activities related to the development of routes are due, inter alia, to the widespread use of online shopping and the behaviours of customers who expect goods to be shipped from any place to the other continent within a few/several days. Most of the cargo is transported from China to Europe by sea. That takes 40 to 60 days. Goods shipped from China by train arrive in Europe within two weeks. Railway transportation is faster than maritime transport and much cheaper than air transport (see Figs. 1 and 2).

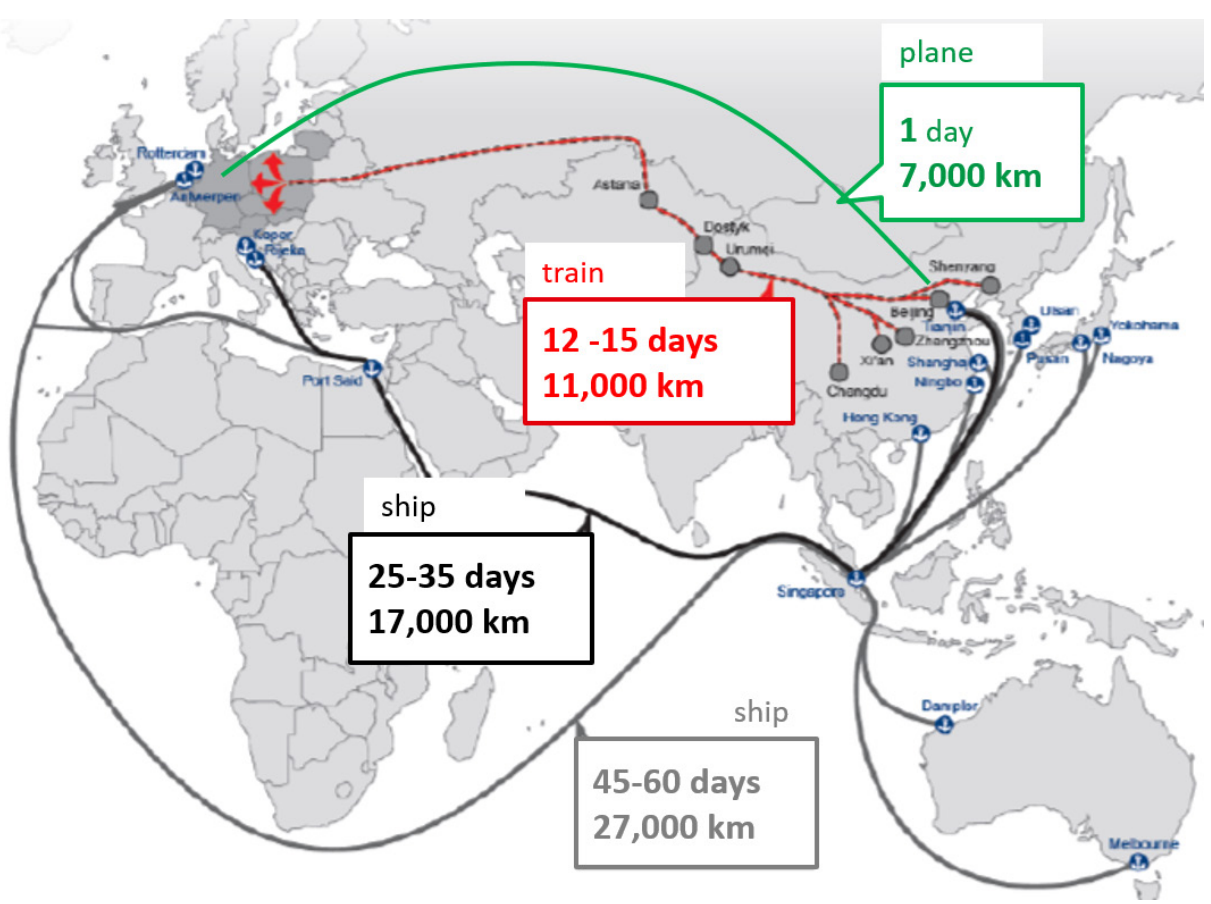

Figure 1. Direction and features of sea, rail, and air routes 


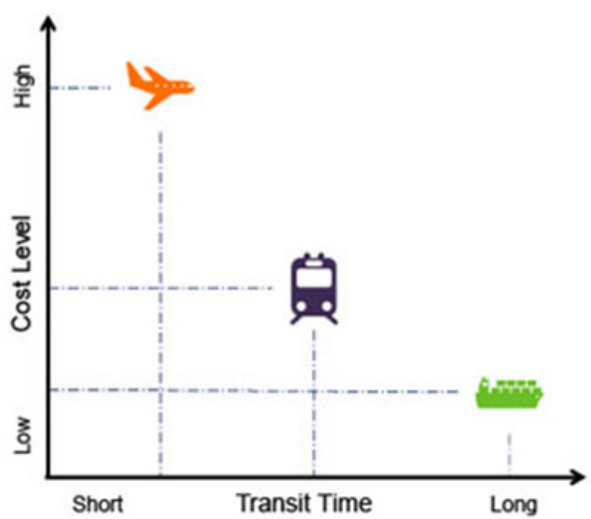

Figure 2. Comparison of means of transport

Source: Authors' own study based on PKP S.A. in-house materials.

The Broad-Gauge Metallurgy Line (also called the "broad track") is the longest broad-gauge railway line designed for freight transport in Poland. Its coverage is shown in Figure 3.

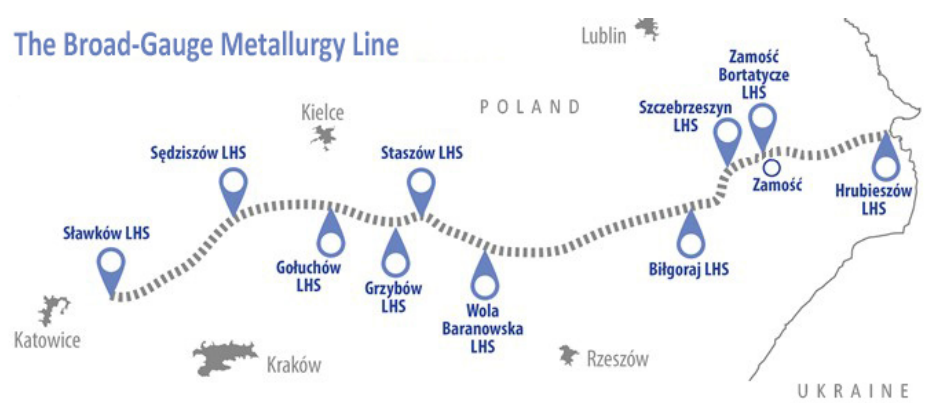

Figure 3. The coverage of the broad-gauge line

Source: Authors' own study based on PKP LHS in-house materials.

The length of the line is $394,650 \mathrm{~km}$. The line has a specific regional coverage. It runs via south-eastern Poland and the Lublin, Podkarpackie, Świętokrzyskie, Małopolskie, and Silesian provinces. The main attributes of the LHS line are that it transports without handling the goods at the border and it can use heavy trains. Railway infrastructure consists of railways with stations, forwarding terminals and equipment such as power substations, communication centres, and command control and signalling equipment. PKP LHS actively promotes the development of rail transport between Europe and Asia, in particular in the field of intermodal transport. In 2016, PKP LHS became a member of the coordinating committee of the Trans-Caspian International Transport Route (the middle corridor, TITR). In 2017, the Company signed 
Pobrane z czasopisma Annales H - Oeconomia http://oeconomia.annales.umcs.pl

Data: 26/04/2023 11:58:57

an agreement on the accession as an associate member of the Association of Legal Entities of the TITR. The Association's activity aims to carry out rail transport from China to Europe via Kazakhstan, the Caspian Sea, Azerbaijan, Georgia, the Black Sea, and Ukraine or Turkey. The coverage of the TITR Corridor is shown on Map 1.

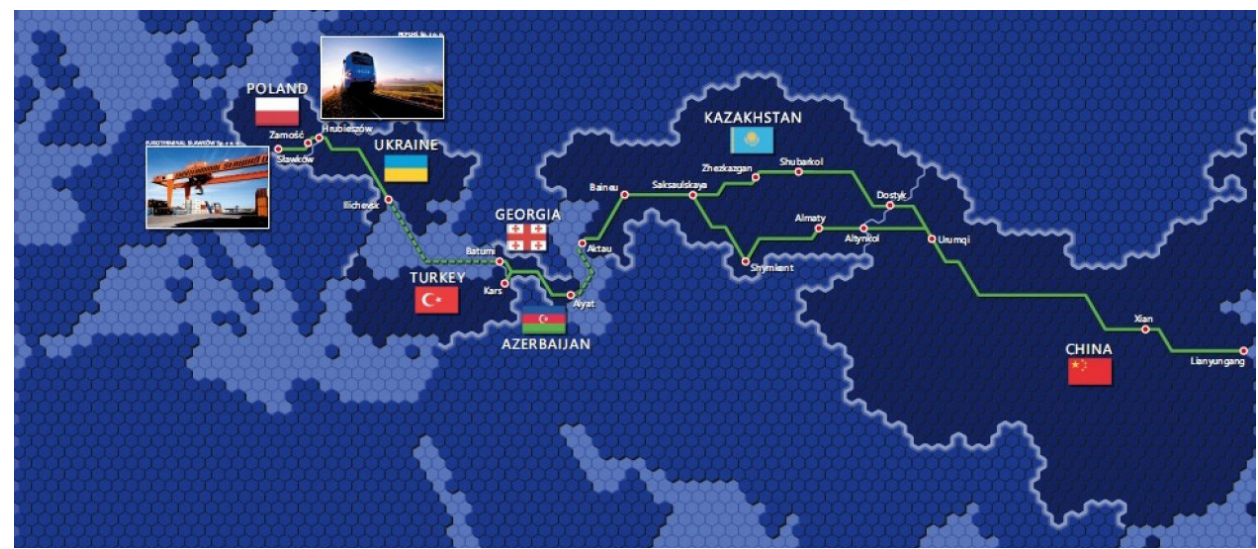

Map 1. The coverage of the TITR corridor

Source: PKP LHS study based on TITR data.

With PKP LHS joining the Association, it is possible to extend the corridor by the westernmost broad-gauge line (see Map 2).

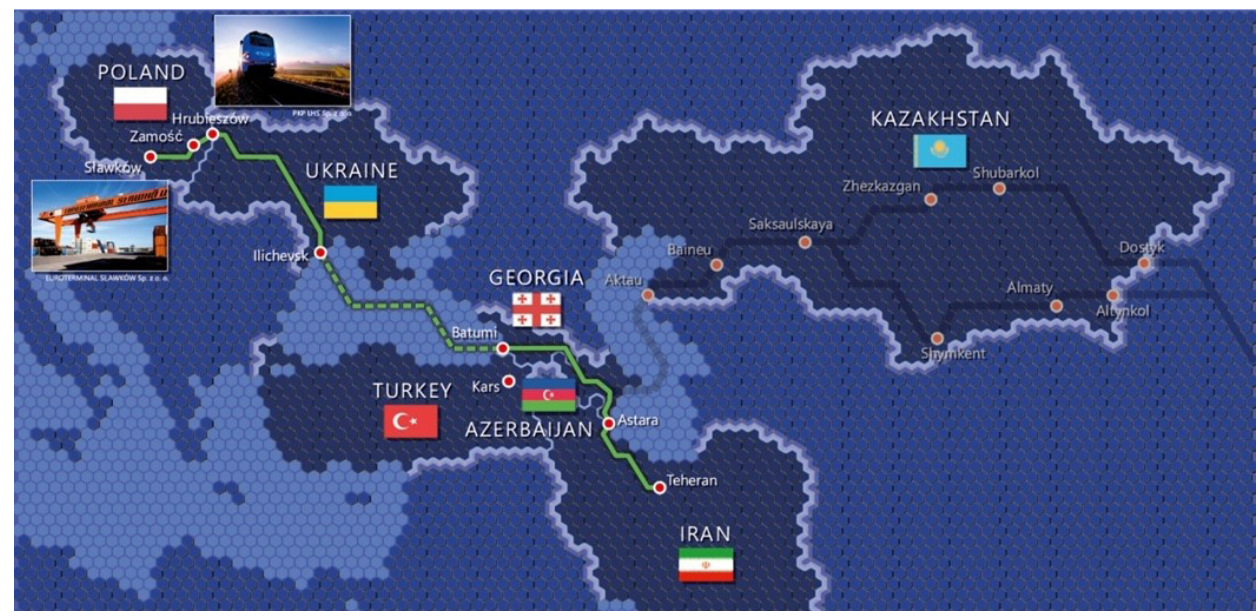

Map 2. The coverage of the South-West route

Source: PKP LHS study based on data about the South-West route. 
The highest volume of container turnover is between China and Western Europe. In 2017, approximately 200,000 TEU were transported by rail from China to Europe. ${ }^{1}$ The basic statistics that the Chinese party uses to promote railway connections is the annual number of trains that have travelled on the routes covered by the China Railway Express project. According to CR Express data, rail transport between China and Europe has been gradually increasing. In the peak year of 2017, 3,673 trains were put into operation. In 2020, 5,000 trains are planned to be put into operation (Song, 2017). Generally, PKP LHS, as a part of the BRI infrastructure, is well equipped to accommodate and carry out transport operations between China and Europe on all possible routes of the $1,520 \mathrm{~mm}$ infrastructure:

- the corridor from China through Kazakhstan, Russia, and Belarus with a junction passing via Ukraine to the border crossing Izov or Hrubieszów and then to Sławków,

- the corridor from China via Russia and Ukraine to Sławków,

- the TITR corridor, and

- the South-West corridor.

The countries in the TITR corridor and the South-West corridor are striving to increase their handling and transhipment capacities by upgrading their transhipment terminals (e.g. Horgos in Kazakhstan and Astar in Azerbaijan). Existing sections of the railway infrastructure are being modernized and new sections of the railway are being constructed. The $\mathrm{B} \& \mathrm{R}$ is a variant-based network of different routes with different coverages. Of critical significance is the ability to direct trains from any NSR network (line) to the border crossing Izov or Hrubieszów, and farther via the broad-gauge line to the Sławków station, without any transhipment at the border. From the Euroterminal Sławków, shipments can be dispatched to the West and South of Europe by standard-gauge railway lines or by road transport. At present, the transport of containers by PKP LHS Sp. z o.o. is carried out by the so-called scattered traffic (individual railcars with containers are attached to fixed train formations). In 2017, container transport amounted to 16,000 TEU. In 2018, LHS's share in the intermodal transport market exceeded 1\% (Rok 2018 w..., 2019, p. 11). Considering the customers' interest in PKP LHS transport services via the Belt and Road and the possibility of running two container trains per day dedicated to this particular route, one should assume a four-fold increase in container transport by PKP LHS. According to PKP LHS estimates, based on the minutes of the General Assembly of TITR of 2018, it is assumed that 60,000 TEU will be transited annually via this transport corridor by 2020. With the connection of LHS with Euroterminal Sławków, situated at the junction of the broad gauge $(1,520 \mathrm{~mm})$ railway line and standard gauge $(1,435 \mathrm{~mm})$ railway line, LHS gains direct access to Polish ports in the Baltic Sea and the possibility to transport goods to both cities and ports in Western and Southern Europe (see Map 3).

$11 \mathrm{TEU}=$ one $20-\mathrm{ft}$ standard container. 


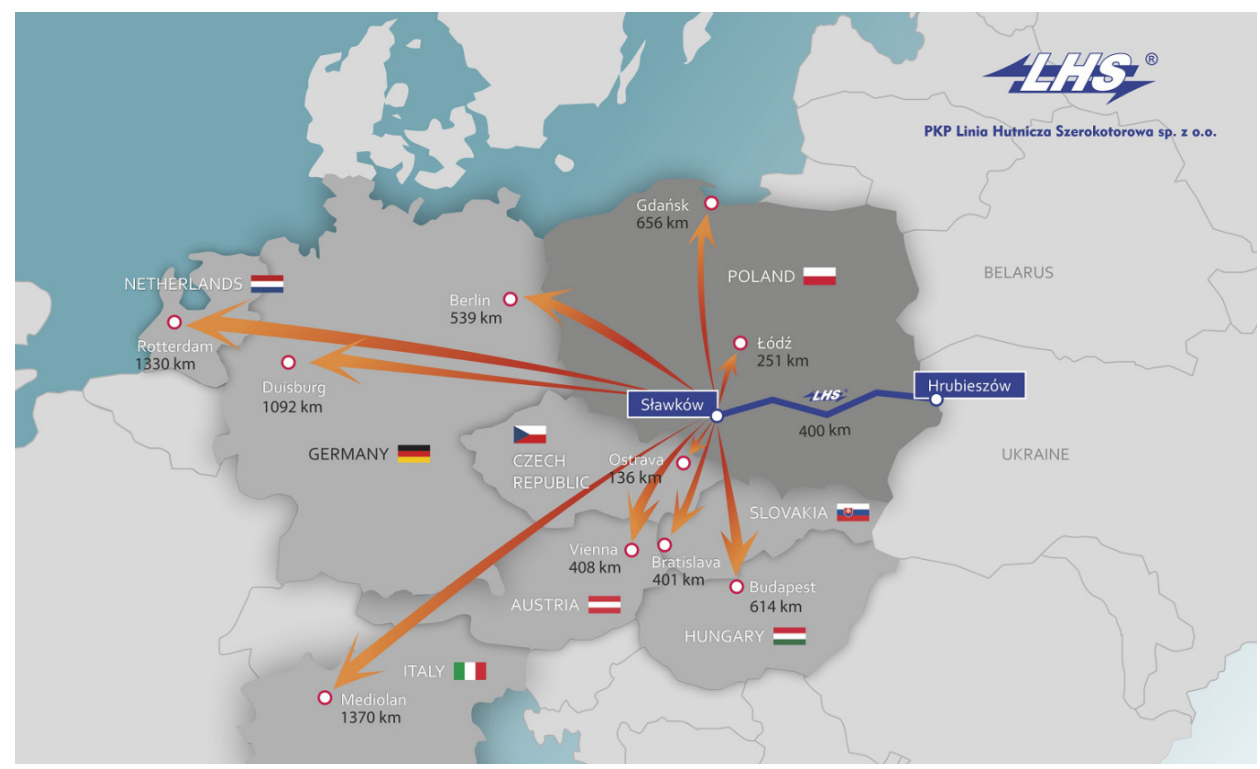

Map 3. Connections from the broad-gauge railway line

Source: PKP LHS study.

Rail transport can satisfy transport needs and requirements to a greater extent in terms of quantity and type of freight. In general, rail transport is cheaper than road transport, and it offers greater transport capacity (Rosa, 2006, p. 119). For the Kazakh-China Border-Sławków route, the estimated time of travel is 16 to 19 days. The line capacity is a minimum of 12 pairs of trains per day. The LHS line operates 10 stations where all types of goods can be transhipped. The following stations are available for the transport of container shipments: Zamość Bortatycze, Szczebrzeszyn, Biłgoraj, Wola Baranowska, Gołuchów, and Sławków. The Euroterminal Sławków can handle container trains on both broad- and standard-gauge tracks. The Euroterminal's transhipment capacity is 300,000 TEU per year. LHS's presence on the Chinese market is reflected in the company's participation in events addressed to Chinese logistics companies responsible for transport to and from Europe. As a result, the offer - especially the one concerning transport via the TITR route from Poland to China - has to be targeted at food industry companies exporting their goods to the Chinese market and to the wider Asian market. This creates new opportunities for the Polish food industry. PKP LHS's efforts to develop railway infrastructure fall within the assumptions of the Strategy for Responsible Development in the area of reindustrialisation (Strategia ..., 2017). One of its elements is also the Silk Road developed, inter alia, by the Company. 


\section{Key investments in the context of Belt and Road in the Lublin Province}

The investments planned in Poland form part of the existing linear and nodal infrastructure. They broaden the perspective of increasing the capacity of the railway network and transhipment terminals used for intermodal transport. This includes both linear infrastructure of paramount importance for intermodal transport due to its speeds and length of trainsets. The reconstruction of the Terespol-Brest border crossing has been considered a crucial part of the planned modernization of the railway infrastructure near the railway border crossings at the junction of the two systems. There are plans to construct a brand-new set of tracks there, dedicated to freight traffic at the Terespol border station, which is to be connected with the Małaszewicze Transhipment Area. The key objective of the comprehensive project is to improve the capacity of the RFC $8^{2}$ corridor along the EU's eastern border with Belarus. This is to be achieved by ensuring greater track system capacity and safety for incoming and outgoing trains, increasing the average train speed and increasing the allowable contact pressure to $245 \mathrm{kN} / \mathrm{axis}$, and implementing a modern control-command and signalling system. The critical element of the linear infrastructure in the context of the development of the Silk Road in the area of Małaszewicze is the planned comprehensive modernization of the infrastructure, including the construction of an auxiliary set of loading/unloading side tracks. Modernisation of the Terespol-Małaszewicze transhipment area is expected to enable it to handle more container trains and provide logistics services in Poland to broad-gauge freight trainsets $1,050 \mathrm{~m}$ long, increasing the average speed of trains to $40 \mathrm{~km} / \mathrm{h}$ and increasing the permissible axle load of cars up to $25 \mathrm{t}$. When the investment is complete, it will be possible to avoid the costs of the forced division of trainsets and to improve the capacity of the Małaszewicze Transhipment Area. According to declarations, the capacity of this largest dry port in Europe is expected to increase fourfold. Moreover, PKP LHS also invests in increasing the capacity of Europe's westernmost broad-gauge railway line No. 65. The Company's investment plan provides for, inter alia, constructing modern systems (centres) for remote control of railway traffic (computer-based interlocking) and modernising lines. By 2025, PKP LHS plans to spend PLN 800 million on investments, including an increase in line capacity up to 16 pairs of trains per day. Today, trains with a maximum speed of $120 \mathrm{~km} / \mathrm{h}$ and a length of $1,050 \mathrm{~m}$ can run along the entire railway line. The funds will also be used to develop a computerized control-command and signalling system and to modernise engines. The key to the long-term, substantial increase in the attractiveness of container rail transport across Poland is the development of a network of high-quality open terminals that enable fast and reliable inter-branch transhipment operations. These facilities should be available throughout Poland. Regarding modernization and construction of new intermodal terminals and logistics centres, further investments have been implemented

2 The second corridor - Northern. 
and scheduled in the Lublin Province (Chełm, Lublin). They are presented in Map 4 , which shows the current status of the nodal infrastructure of key importance for intermodal transport along the Belt and Road.

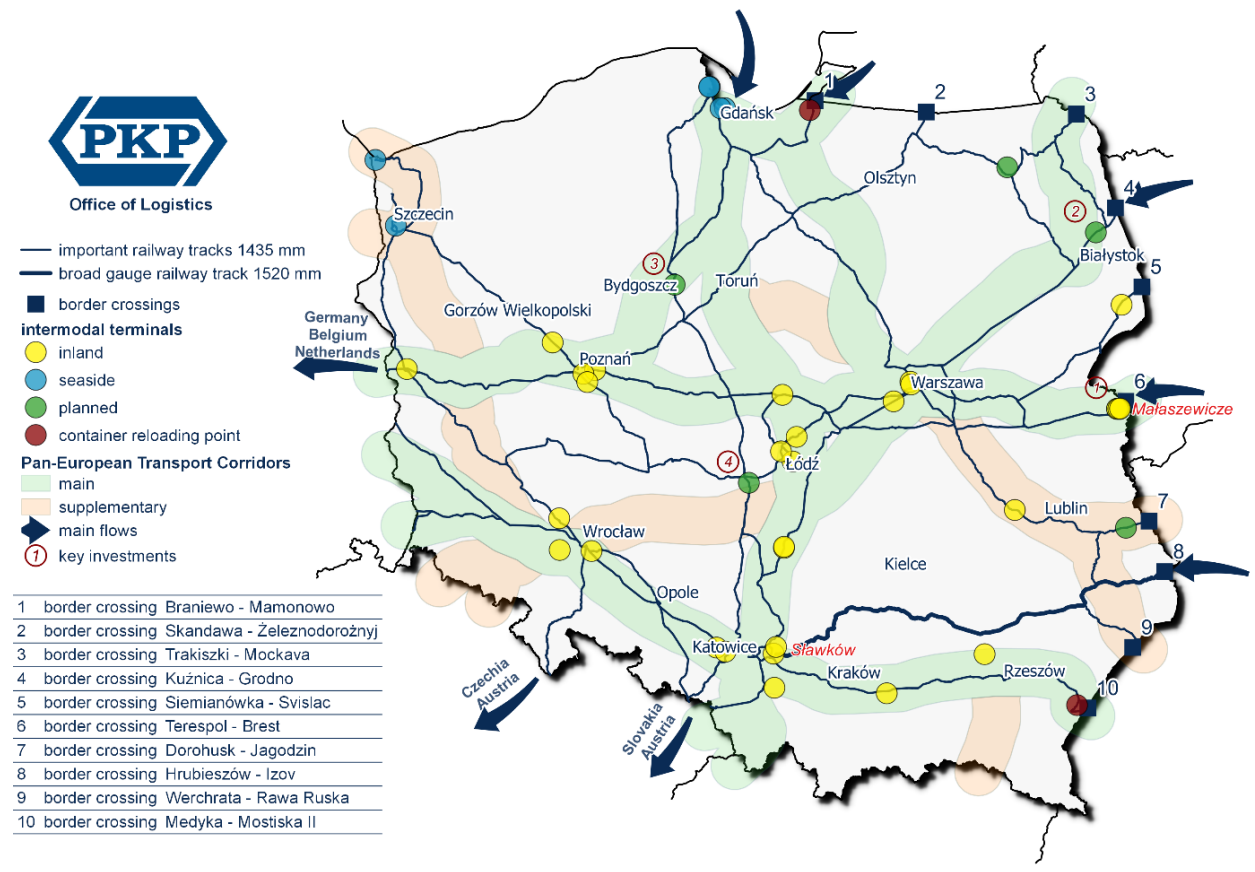

Map 4. Main intermodal terminals in Poland

Source: PKP S.A. in-house materials.

The current economic situation of the Lublin Province and the influence of infrastructure investments on regional development

The Lublin Province is the third largest province in Poland, with an area of over $25,000 \mathrm{~km}^{2}$. Its eastern border is also a boundary line of the European Union. According to GUS data from 2019, the Lublin Province is the $11^{\text {th }}$ province in Poland in terms of gross domestic product. In 2017, its GPD reached over PLN 71,270 million and PLN 33,371 per capita. Sectors with high potential, established by the Polish Investment \& Trade Agency and the government of the Lublin Province with observed trends in regional investment in mind, have important roles in the regional development strategy. Energy, agri-food, machine, logistics, BPO, and tourism are among the fastest developing sectors in this region. 
Investments can be conducted in special zones on preferential terms offered by Special Economic Zones of Mielce, Starachowice, Pomorze, and Tarnobrzeg, in the following subsectors:

- SEZ Mielecka,

- SEZ Pomorska,

- SEZ Starachowicka, and

- SEZ Tarnobrzeska.

In all these areas, investors can receive an exemption from income tax of 50 to $70 \%$, depending on the company scale.

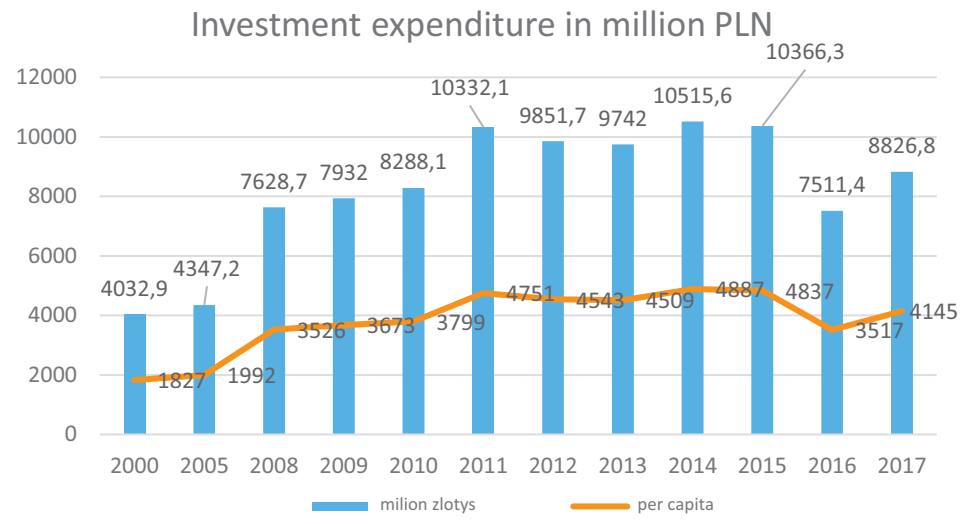

Figure 4. Investment expenditure in the Lublin Province

Source: In-house analysis based on GUS data from 2017.

GUS reports show that investment expenditure in the Lublin Province slowed down after the bull market of 2011-2015. Despite measures to decrease the gap between the Lublin Province and Poland's most developed areas, the investments are still highly disproportionate. The GDP of the Warsaw region is 4.5 times bigger than the GDP of Lublin Province. The GDP per capita in Warsaw is 3 times bigger than in the Lublin Province. Moreover, PKP LHS's current projects, which are over PLN 800 million, are perceived as a major investment, given the regional scale of Lubelskie.

According to Myna (2010), well developed supra-regional transportation network positively affects the region and its development of industrial sectors and services, as well as foreign investments. Redding and Venables (2004) demonstrated that imbalance in GDP per capita between regions is highly dependent on access to the market and resources. The Lublin Province is one of the regions with the least developed density of the railway network. The length of the standard railway is less than $1,050 \mathrm{~km}$, and it has not changed for almost 20 years. That length is not sufficient by today's standards. It affects the communication accessibility of the region. The Eastern Poland Development Programme, implemented by PKP PLK, will bring much-needed improvements. The benefits of an increase in the transportation sector 
are not only positively affecting the carrier (freight), but also raising income from cargo operations. It also increases income from customs services (at the border of the EU) and taxes collected by the government. Equally important are new workplaces that are generated by the development of logistics. It is a great tool for Polish exporters, and a mean to attract new investments.

\section{Summary}

Can PKP LHS become an alternative transportation route for cargo coming from Asia, which is currently transhipped on standard railway lines and ports on the EU borders? Can railway transportation become an alternative route to existing maritime routes and air routes? What are the planned investments, the possibilities of growth in the cargo transportation sector, and the chances of development for the Lublin Province?

The Belt and Road Initiative is a chance for developing not only the broad-gauge railway line, which is operated by PKP LHS, but also the regions that are connected with it, particularly the Lublin Province, in which the border station, company headquarters, and longest section of the Polish broad-gauge railway line are located. An important investment programme, currently being conducted by the company, is increasing the chances of opening up alternatives for transportation between Asia and Europe. Transportation via the middle corridor is faster than maritime transport and cheaper than air transport. If the plans of regular container shipments to and from Asia are implanted, the region will receive various benefits and a stimulus for local companies, agriculture, and cargo transportation. By strengthening cooperation and increasing commercial exchange, the economy of the regions along the route will experience greater growth, and they will increase consumption, investments, and global demand. Considering the development of the Belt and Road Initiative and the constantly increasing cargo transportation needs between China and Europe, modernising the infrastructure of the Lublin Province must be considered. Moreover, building a new terminal and logistics centre may attract streams of cargo into Eastern Poland. It is a chance for further growth of this region in terms of the local economy, labour market, culture, and development of local communities. If PKP LHS joins the corridor, it will create more opportunities to increase trade between EU countries and China, with transit via Polish territory. Expansion of transportation from China will mean using alternative railway routes that lead through Ukraine to Poland. 


\section{References}

Hubner, W., Rybicka, M., \& Wieszczycka, W. (2016). Azja XXI wieku i renesans szlaku Jedwabnego. Warszawa: Wydawnictwo Vistula.

Jakóbowski, J., Popławski, K., \& Kaczmarski, M. (2018). Kolejowy Jedwabny Szlak. Warszawa: Ośrodek Studiów Wschodnich.

Myna, A. (2010). Uwarunkowania i skutki niedorozwoju ponadregionalnej infrastruktury transportowej na przykładzie województwa lubelskiego. Barometr Regionalny, 2(20).

Program strategicznego rozwoju transportu województwa lubelskiego. (2017). Lublin.

Redding, S., \& Venables, A.J. (2004). Economic Geography and International Inequality. Journal of International Economics, 62(1).

Rok 2018 w przewozach intermodalnych. Podsumowanie Prezesa UTK. (2019). Warszawa: Urząd Transportu Kolejowego.

Rosa, G. (2006). Ustugi transportowe: rynek, konkurencja, marketing. Szczecin: Wydawnictwo Naukowe Uniwersytetu Szczecińskiego.

Song, D. (2016). New Eurasian Land Bridge: Achievements \& Challenges, General Manager Sinotrans \& CSC Holdings Co. Ltd., presentation. The $2^{\text {nd }}$ Conference of the Ministers of Transport (TMM) and Business Forum, 26 October 2016, Warsaw

Strategia na rzecz Odpowiedzialnego Rozwoju do roku 2020 (z perpektywa do 2030 r.). (2017). Warszawa: Ministerstwo Rozwoju.

\section{Internet sources}

www 1, http://container-news.com/containers-asia-europe-volume/ www 2, http://trade.ec.europa.eu/doclib/docs/2011/january/tradoc_147207.pdf www 3, http://appsso.eurostat.ec.europa.eu/nui/show.do?dataset=ext_lt_intratrd\&lang=en 